\title{
GYPSUM-SATURATED WATER TO RECLAIM ALLUVIAL SALINE SODIC AND SODIC SOILS
}

\author{
Karien Rodrigues da Silveira ${ }^{1}$; Mateus Rosas Ribeiro ${ }^{1 *}$; Luiz Bezerra de Oliveira ${ }^{2}$; Richard \\ John Heck ${ }^{3}$; Rachel Rodrigues da Silveira ${ }^{1}$ \\ ${ }^{1}$ UFRPE - Depto. de Agronomia, R. Dom Manoel de Medeiros, s/no - Dois Irmãos - 52171-900 - Recife, PE - \\ Brasil. \\ ${ }_{3}^{2}$ Embrapa Solos/UEP - Recife, R. Antonio Falcão, 402 - 51020-240 - Recife, PE - Brasil. \\ ${ }^{3}$ University of Guelph - Dept. of Land Resources Science - Guelph, Ontario - N1G 2W1 - Canada. \\ *Corresponding author<mrosas@depa.ufrpe.br>
}

ABSTRACT: Inadequate management of soil and irrigation water contribute to soil degradation, particularly in the alluvial areas of Northeast Brazil, where salinity and sodicity are already common features. This study evaluates the effects of the addition of gypsum in the irrigation water on physical and chemical properties of soils with different levels of salinity and sodicity. Samples were collected at the Custódia irrigation area of Brazil, predominantly covered by alluvial soils. Leaching tests using simulated irrigation water classified as $\mathrm{C}_{3} \mathrm{~S}_{1}$, and gypsum-saturated irrigation water were carried out in soil columns of 20 and $50 \mathrm{~cm}$ depth. Soil leaching with gypsum saturated water $\left(\mathrm{T}_{2}\right)$ resulted in an increase in the amounts of exchangeable calcium and potassium, and in a decrease of soil $\mathrm{pH}$, in relation to the original soil $\left(\mathrm{T}_{0}\right)$, with significant statistical differences to the treatment using only water $\left(\mathrm{T}_{1}\right)$. There was a reduction in the electrical conductivity, exchangeable sodium and exchangeable sodium percentage in both treatments $\left(T_{1}\right.$ and $\left.T_{2}\right)$, with treatment $T_{2}$ being more effective in the leaching of soil sodium. No changes of electrical conductivity, calcium and $\mathrm{pH}$ in depth were observed, but the $20-50 \mathrm{~cm}$ layer presented higher amounts of magnesium, sodium and exchangeable sodium percentage. Gypsum saturated water improved the hydraulic conductivity in both layers. The use of gypsum in the irrigation water improved soil physical and chemical properties and should be considered as an alternative in the process of reclamation of saline-sodic and sodic soils in Northeast Brazil.

Key words: salt affected soils, irrigation, reclamation, management

\section{ÁGUA SATURADA COM GESSO NARECUPERAÇÃO DE SOLOS ALUVIAIS SALINO-SÓDICOS E SÓDICOS}

RESUMO: O manejo inadequado do solo e da água de irrigação contribui para a degradação dos solos, particularmente nas áreas aluviais do Nordeste do Brasil, onde a salinidade e a sodicidade são características comumente observadas. Avaliaram-se os efeitos da adição do gesso na água de irrigação, sobre as propriedades físicas e químicas de solos com diferentes níveis de salinidade e sodicidade. Foram utilizadas amostras de solos provenientes do perímetro irrigado de Custódia, em Pernambuco, coletadas em uma área de solos aluviais. Foram feitos testes de lixiviação com água de composição semelhante à do açude de Custódia, classificada como $\mathrm{C}_{3} \mathrm{~S}_{1}$, e com água saturada com gesso, em colunas de solo de 20 e $50 \mathrm{~cm}$ de profundidade. A lixiviação do solo com água saturada com gesso $\left(\mathrm{T}_{2}\right)$ aumentou os teores de cálcio e potássio do solo e reduziu o $\mathrm{pH}$ em relação ao solo original $\left(\mathrm{T}_{0}\right)$, diferindo do tratamento de lixiviação com água $\left(\mathrm{T}_{1}\right)$. Houve redução da condutividade elétrica, do teor de sódio trocável e da percentagem de sódio trocável do solo nos dois tratamentos $\left(T_{1}\right.$ e $\left.T_{2}\right)$, sendo que o tratamento $\mathrm{T}_{2}$ mostrou-se mais eficiente quanto à remoção do sódio. Os valores de condutividade elétrica, cálcio e $\mathrm{pH}$ não diferiram nas duas profundidades, mas a camada de $20-50 \mathrm{~cm}$ apresentou maiores teores de magnésio, sódio e percentagem de sódio trocável. A água saturada com gesso aumentou a condutividade hidráulica do solo em todo o perfil estudado. O uso do gesso na água de irrigação promoveu uma melhoria das condições físicas e químicas dos solos, podendo ser uma alternativa no processo de recuperação de solos salino-sódicos e sódicos no Nordeste do Brasil. Palavras-chave: solos afetados por sais, irrigação, correção, manejo

\section{INTRODUCTION}

Irrigation is the most important practice to sta- bilize crop production in arid and semi-arid regions. However, the high evapotranspiration rates and low precipitation can increase salt concentration, resulting 
in soil salinization and alkalization, reducing soil productivity and threatening the sustainability of the agricultural system. Inadequate management of soil and irrigation water can also contribute to soil degradation, particularly in the alluvial areas of Northeast Brazil, where salinity and sodicity are already common features.

Studies on the reclamation of salt affected soils have been carried out for decades. Reclamation can be considered a high cost operation, requiring good quality water and the use of chemical amendments. However, it can technically be accomplished only in places where irrigation and drainage are available. Although saline soils only require salt leaching, the reclamation of saline-sodic and sodic soils requires the exchange of sodium to calcium before the leaching of soluble salts (Kelley, 1951; USSL hStaff, 1954; Pizarro, 1978; Bresler et al., 1982). Gypsum is the most common amendment used in the reclamation of saline-sodic and sodic soils, due to its great availability and low price (Santos \& Ferreyra, 1997).

Studies carried out in Brazil and other countries (Shainberg et al., 1982; Pereira et al., 1986; Melo et al., 1988; Barros \& Magalhães, 1989; Chaves \& Rolim, 1997) about the use of gypsum for the reclamation of sodic soils have shown that the low solubility of gypsum affects its efficiency when applied to the soil, requiring larger amounts of water to dissolve it and longer periods of time for the reaction than other amendments. The efficiency of the gypsum depends on several factors such as type of application, solubility, particle size, soil solution composition and soil physical properties.

Gypsum saturated irrigation water improves the infiltration rate due to the fast exchange reaction with soil exchangeable sodium and the increase in salt concentration of the soil solution, improving its efficiency and reducing the amount of applied gypsum (Axtell \& Doneen, 1949; Anjos, 1993). The application of gypsum in the irrigation water has shown better results with low salinity waters $\left(\mathrm{EC}<0.2 \mathrm{dS} \mathrm{m}^{-1}\right)$ or with water of high SAR values, and low to moderate salinity $\left(\mathrm{EC}<1 \mathrm{dS} \mathrm{m}^{-1}\right)$. When water salinity is high the application into the soil is recommended (Ayers \& Westcot, 1991).

The objective of this study was to evaluate the efficacy of gypsum applied in the irrigation water for the reclamation and improvement of saline-sodic and sodic alluvial soils in Northeast Brazil.

\section{MATERIAL AND METHODS}

\section{Soil characteristics}

Soils belong to the irrigation area of Custódia municipality, in the Sertão Zone of the Pernambuco State, Brazil ( $8^{\circ} 05^{\prime}$ S, $37^{\circ} 37^{\prime}$ W). Samples were collected from the $0-20$ and $20-50 \mathrm{~cm}$ depths, at six locations with different salinity and sodicity levels, either in surface and subsurface layers. Sites were chosen according to a previous study in a 16 ha farm block, characterized by alluvial soils classified as Neossolos Flúvicos (Fluvents), according to the Brazilian system of soil classification (Ribeiro, 1999). Soil samples were air dried and ground to pass a $2 \mathrm{~mm}$ sieve to obtain the fine earth fraction used in the experiment.

\section{Packing and leaching of soil columns}

The experiment involved leaching tests in order to evaluate the effect of gypsum applied in the irrigation water on the improvement of soil physical and chemical properties. The tests were carried out using water with similar composition to the Custódia reservoir, classified as $\mathrm{C}_{3} \mathrm{~S}_{1}$ (USSL Staff, 1954), gypsum saturated water, and soil columns with 20 and $50 \mathrm{~cm}$ height. The experiment was carried out under laboratory conditions, using disturbed soil samples and a system of inverted flow of water, with constant hydraulic head. Details of the equipment can be observed in Figure 1.

Soil columns were reconstructed in PVC tubes, using the fine earth from samples collected at 0 - 20 and $20-50 \mathrm{~cm}$ depths, based on an average soil bulk density of $1.52 \mathrm{~kg} \mathrm{dm}^{-3}$ and an internal area of $17.35 \mathrm{~cm}^{2}$. Tubes were filled in portions of $52.7 \mathrm{~g}$ of fine earth, which is equivalent to $2.0 \mathrm{~cm}$ of column thickness, followed by packing. Soil columns of 20 and $50 \mathrm{~cm}$ were mounted in an inverse position, from the top soil to the bottom.

Soil leaching was carried out in two steps: first, soil columns of 20 and $50 \mathrm{~cm}$ depth were leached

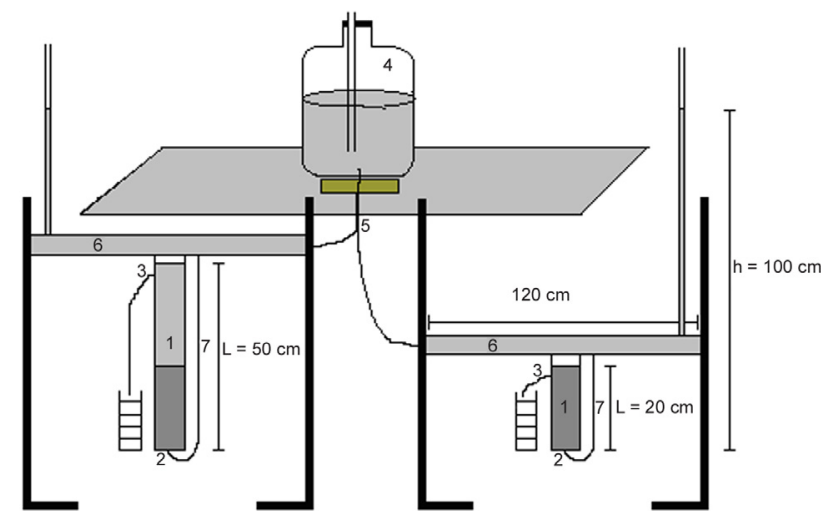

Figure 1 - Schematic diagram of the leaching assembly. 1: Soil columns. 2: Supply holes. 3: Leachate collection holes. 4: Mariotte bottle. 5: Supply tube. 6: PVC tubes. 7: Supply hoses to inverted soil columns. 
with water classified as $\mathrm{C}_{3} \mathrm{~S}_{1}$, and the leaching solution volume measured each 24 hours. In the second step, with new columns, gypsum-saturated water was used. Solutions were applied with the soil at $-0.01 \mathrm{MPa}$ of matric potential. The measurement finished when the amount of the leaching solution was constant, which occurred after 10 days. Electrical conductivity and $\mathrm{pH}$ were measured after each collection.

The experiment was set up in a random design with three treatments: original soil (T0), water leached soil (T1) and gypsum saturated water leached soil (T2); two layers $(0-20$ and $20-50 \mathrm{~cm})$ and 6 sampling locations. The statistical analysis of variance were proceeded according to Gomes (1974), and means were compared by the Tukey test $P=0.05$.

\section{Soil physical analyses}

Physical analyses were carried out using the EMBRAPA (1997) methodology, except for the soil hydraulic conductivity, determined by means of the equipment shown in Figure 1. Particle size distribution (Bouyoucos hydrometer method), soil bulk density (cylinder method) and moisture content at tensions of 0.033 and $1.5 \mathrm{MPa}$ (Richards, 1974) were determined. During the leaching experiment the saturated hydraulic conductivity $\left(\mathrm{K}, \mathrm{cm} \mathrm{h}^{-1}\right)$ was measured at each $24 \mathrm{~h}$ and determined by application of Darcy' s law, in an inverted flow system: $\mathrm{K}=[(\mathrm{Q} / \mathrm{A})] \mathrm{L} /(\mathrm{h}-\mathrm{L})$, where $\mathrm{Q}=$ volume passing through soil sample $\left(\mathrm{cm}^{3} \mathrm{~h}^{-1}\right) ; \mathrm{A}=$ transversal section of the soil sample $\left(\mathrm{cm}^{2}\right) ; \mathrm{h}=$ hydraulic head $(\mathrm{cm}) ; \mathrm{L}=$ Length of the soil column $(\mathrm{cm})$.

\section{Soil chemical analyses}

Soil chemical analyses were also determined according to the EMBRAPA (1997) methodology. Before the leaching test, soil $\mathrm{pH}, \mathrm{pH}$ and electrical conductivity of the saturation extract (EC), soluble salts, exchangeable cations, cation exchange capacity (CEC) and exchangeable sodium percentage (ESP) were determined. After leaching, analysis of the soil exchangeable complex, EC and $\mathrm{pH}$ of the leaching solution were also performed.

\section{RESULTS AND DISCUSSION}

\section{Soil properties before leaching}

Soil samples are dominantly medium textured, with larger amounts of silt than clay (Table 1). The dispersion indexes were larger than $60 \%$ in $83 \%$ of samples in the subsurface layer $(20-50 \mathrm{~cm})$, which define soils with poor structural arrangement and low permeability, requiring improvement of the drainage conditions. Soil and particle densities showed 1.49 and $2.56 \mathrm{~kg} \mathrm{dm}^{-3}$ mean values, respectively, and total porosity varied from 38.7 to $43.0 \%$.

In the saturation extract (Tables 2 and 3), the $\mathrm{pH}$ ranged from 7.58 and 8.68 , with $90 \%$ of the samples with $\mathrm{pH}$ values equal or greater than 8.0 ; the electrical conductivity varied between 1.15 and 8.76 $\mathrm{dS} \mathrm{m}{ }^{-1}$, with $50 \%$ of the values, below $4.0 \mathrm{dS} \mathrm{m}^{-1}$, classified as non saline and $50 \%$ classified as saline. The concentration of soluble ions in most samples was $\mathrm{Na}^{+}>\mathrm{Ca}^{2+}>\mathrm{Mg}^{2+}>\mathrm{K}^{+}$, for the cations, and $\mathrm{Cl}^{-}>\mathrm{HCO}_{3}^{-}>\mathrm{SO}_{4}^{2-}>\mathrm{CO}_{3}^{2-}$, for the anions.

Table 1 - Physical properties of the soil samples before leaching $\left(\mathrm{T}_{0}\right)$.

\begin{tabular}{|c|c|c|c|c|c|c|c|c|c|c|c|}
\hline \multirow{2}{*}{ Soil } & \multirow{2}{*}{ Depth } & \multicolumn{3}{|c|}{ Particle size distribution } & \multirow{2}{*}{$\begin{array}{l}\text { Disp. }^{(1)} \\
\text { Index }\end{array}$} & \multirow{2}{*}{ Ds } & \multirow{2}{*}{$\mathrm{Dp}$} & \multirow{2}{*}{$\mathrm{Pt}$} & \multicolumn{2}{|c|}{ Water content } & \multirow{2}{*}{$\begin{array}{c}\text { Available } \\
\text { water }\end{array}$} \\
\hline & & Sand & Silt & Clay & & & & & $1.5 \mathrm{MPa}$ & $0.03 \mathrm{MPa}$ & \\
\hline & $\mathrm{cm}$ & \multicolumn{3}{|c|}{ - } & $\%$ & \multicolumn{2}{|c|}{$-\ldots \mathrm{g} \mathrm{dm}^{-3} \ldots$} & - & (n-n & $\%$ & (n- \\
\hline $\mathrm{P} 1$ & $0-20$ & 305.2 & 430.0 & 264.8 & 59.82 & 1.46 & 2.53 & 42.29 & 7.99 & 18.59 & 10.60 \\
\hline $\mathrm{P} 1$ & $20-50$ & 435.2 & 315.0 & 249.8 & 86.31 & 1.47 & 2.56 & 42.58 & 9.34 & 19.39 & 10.05 \\
\hline $\mathrm{P} 2$ & $0-20$ & 389.6 & 320.0 & 290.4 & 55.79 & 1.46 & 2.56 & 42.97 & 7.04 & 15.99 & 8.95 \\
\hline $\mathrm{P} 2$ & $20-50$ & 422.4 & 280.0 & 297.6 & 80.38 & 1.47 & 2.56 & 42.58 & 10.87 & 19.54 & 8.67 \\
\hline P3 & $0-20$ & 465.2 & 290.0 & 244.8 & 70.26 & 1.47 & 2.56 & 42.58 & 8.46 & 17.49 & 9.03 \\
\hline P3 & $20-50$ & 465.2 & 270.0 & 264.8 & 67.67 & 1.48 & 2.55 & 41.96 & 8.62 & 16.06 & 7.44 \\
\hline P4 & $0-20$ & 475.2 & 275.0 & 249.8 & 72.86 & 1.49 & 2.66 & 43.98 & 9.31 & 19.48 & 10.17 \\
\hline $\mathrm{P} 4$ & $20-50$ & 415.2 & 300.0 & 284.8 & 41.85 & 1.50 & 2.56 & 41.40 & 10.41 & 19.89 & 9.48 \\
\hline P5 & $0-20$ & 449.6 & 280.0 & 270.4 & 56.21 & 1.48 & 2.53 & 41.50 & 8.26 & 16.76 & 8.50 \\
\hline P5 & $20-50$ & 318.8 & 320.0 & 361.2 & 70.76 & 1.47 & 2.56 & 42.60 & 11.21 & 23.00 & 11.79 \\
\hline P6 & $0-20$ & 445.2 & 330.0 & 224.8 & 49.82 & 1.52 & 2.56 & 40.60 & 7.75 & 14.78 & 7.03 \\
\hline P6 & $20-50$ & 435.2 & 300.0 & 264.8 & 77.64 & 1.57 & 2.56 & 38.67 & 7.92 & 20.49 & 12.57 \\
\hline
\end{tabular}


Soil $\mathrm{pH}$ values indicate slightly alkaline soil reaction in most samples. In general CEC values were greater than in the saline-sodic alluvial soil described by Barros \& Magalhães (1989), from the Moxotó Irrigation Perimeter $\left(\mathrm{CEC}=10.88 \mathrm{cmol}_{\mathrm{c}} \mathrm{kg}^{-1}\right)$, and smaller than the ones described by Melo (1991) (19.60 $\mathrm{cmol}_{\mathrm{c}} \mathrm{kg}^{-1}$ ).

With exception to sample $\mathrm{P} 1_{0-20}$, all samples showed sodic or solodic properties being, therefore, adequate to the objectives of this study. Sodium exchangeable percentages of samples $\mathrm{P} 1_{20-50} ; \mathrm{P} 2_{0-20}$; $\mathrm{P} 2_{20-50} ; \mathrm{P} 4_{0-20} ; \mathrm{P} 4_{20-50}$ and $\mathrm{P} 5_{20-50}$ were greater than the critical value of $15 \%$, used to define the sodic property (Richard, 1974) and are in the same range of ESP values observed by Barros \& Magalhães (1989) and Pereira (1981) in the soils of the Moxoto Irrigation Area-PE. Exchangeable sodium percentages (ESP) contribute to poor soil physical conditions, and several authors have shown their negative effects on soil properties, even in values smaller than $15 \%$ percent (Raij, 1986; Sumner, 1995).

Based on the electrical conductivity results of the saturation extract (Table 2), soil $\mathrm{pH}$ and exchangeable sodium percentage (Table 3 ), $25 \%$ of samples were classified as non saline, $16.67 \%$ as saline, $41.67 \%$ as saline-sodic and $16.67 \%$ as sodic (Richard, 1974), involving several levels of salinity and sodicity, emphasizing the great variability of these properties in alluvial plains.

\section{Soil properties after leaching}

Exchangeable sodium percentage was not reduced in all samples after leaching with water (T1), remaining high in samples $\mathrm{P} 1_{20-50}$ and $\mathrm{P} 2_{20-50}$, with values of 14.71 and $32.25 \%$, respectively (Table 4). Moreover, half of the samples still exhibited ESP $>7$, which is considered limiting for soil physical stability. These values were observed in the $20-50 \mathrm{~cm}$ layer, where water infiltrates with greater difficulty due to the lower hydraulic head. These results also demonstrate the importance of the exchange of sodium by calcium in order to improve the hydraulic conductivity and leaching.

Comparing the difference between soil ESP of $\mathrm{T} 0$ and T1 $\left(\mathrm{ESP} \Delta_{\mathrm{i}-\mathrm{f}}\right)$, it was observed that the non saline samples $\left(\mathrm{P} 1_{0-20}, \mathrm{P} 3_{20-50}\right.$ and $\left.\mathrm{P} 6_{20-50}\right)$ showed small increases, while the others had their ESP decreased in relation to the original sample.

Salt concentration increased in sample $\mathrm{P} 2_{20-50}$, due to its high exchangeable sodium percentage which inhibited leaching. Furthermore this layer was enriched by salt percolation from the surface layer $(0-20 \mathrm{~cm})$. Most samples became non-saline after leaching. Equilibrium was observed between the applied water and the soil solution after leaching, with EC values close to that of water $\left(\mathrm{EC}=1.07 \mathrm{dS} \mathrm{m}^{-1}\right)$. Leaching the soil with gypsum saturated water (Table 4, T2) reduced ESP of all samples to values smaller than the critical (ESP $\geq 15$ ), with major reduction in the layer 0 - 20 $\mathrm{cm}$. An increase in the ESP of the non-saline samples was observed in a smaller proportion than in the samples submitted to treatment T1, except for sample $\mathrm{P} 3_{20-50}$.

The difference between the initial and final concentration $\left(\mathrm{EC} \Delta_{\mathrm{i}-\mathrm{f}}\right)$ showed that salinity increased in

Table 2 - Results of the samples saturation extracts before leaching treatments $\left(\mathrm{T}_{0}\right)$.

\begin{tabular}{|c|c|c|c|c|c|c|c|c|c|c|c|c|}
\hline \multirow{2}{*}{ Samples } & \multirow{2}{*}{$\mathrm{pH}$} & \multirow{2}{*}{$\mathrm{EC}^{(1)}$} & \multirow{2}{*}{$\mathrm{SP}^{(2)}$} & \multicolumn{4}{|c|}{ Soluble cations } & \multirow[b]{2}{*}{$\mathrm{CO}_{3}^{2-}$} & \multicolumn{3}{|c|}{ Soluble anions } & \multirow{2}{*}{$\mathrm{SAR}^{(3)}$} \\
\hline & & & & $\mathrm{Ca}^{2+}$ & $\mathrm{Mg}^{2+}$ & $\mathrm{Na}^{+}$ & $\mathrm{K}^{+}$ & & $\mathrm{HCO}_{3}^{-}$ & $\mathrm{SO}_{4}{ }^{2-}$ & $\mathrm{Cl}^{-}$ & \\
\hline & & $\mathrm{dS} \mathrm{m}^{-1}$ & $\%$ & - - - - & & $-\cdots$ & 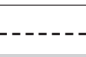 & $\mathrm{mmol}_{\mathrm{c}} \mathrm{L}$ & $1 \ldots$ & 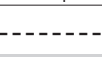 & & (n) \\
\hline P1 $0-20$ & 7.58 & 1.15 & 36.62 & 4.25 & 4.52 & 4.60 & 1.39 & 0.00 & 10.00 & 1.08 & 3.00 & 2.19 \\
\hline$P 120-50$ & 8.05 & 5.23 & 33.30 & 12.10 & 11.12 & 35.22 & 0.13 & 0.00 & 3.00 & 2.38 & 48.00 & 10.33 \\
\hline P2 $0-20$ & 8.02 & 8.00 & 34.61 & 19.90 & 15.17 & 41.39 & 1.40 & 0.00 & 19.00 & 0.83 & 60.00 & 9.88 \\
\hline P2 20-50 & 8.62 & 8.76 & 39.33 & 9.88 & 13.54 & 63.78 & 1.19 & 1.00 & 23.50 & 9.89 & 52.00 & 18.64 \\
\hline P3 $0-20$ & 8.06 & 3.95 & 36.01 & 10.80 & 8.94 & 26.08 & 2.00 & 0.00 & 20.00 & 0.17 & 27.00 & 8.30 \\
\hline P3 20-50 & 8.22 & 3.32 & 36.49 & 8.81 & 8.23 & 17.85 & 1.13 & 0.00 & 14.00 & 5.00 & 18.00 & 6.11 \\
\hline P4 $0-20$ & 8.68 & 8.10 & 35.53 & 9.30 & 8.70 & 70.63 & 0.36 & 2.00 & 2.00 & 5.31 & 68.00 & 23.54 \\
\hline P4 20-50 & 8.20 & 3.06 & 33.31 & 7.05 & 7.35 & 18.20 & 0.39 & 0.00 & 13.50 & 1.90 & 26.00 & 6.78 \\
\hline P5 $0-20$ & 8.55 & 4.04 & 38.04 & 10.60 & 14.14 & 17.43 & 1.75 & 1.00 & 12.70 & 7.96 & 19.00 & 4.95 \\
\hline P5 20-50 & 8.00 & 3.68 & 35.04 & 12.80 & 18.19 & 17.51 & 1.28 & 0.00 & 9.50 & 7.80 & 19.00 & 4.45 \\
\hline P6 0-20 & 8.03 & 7.30 & 35.98 & 33.10 & 12.99 & 34.73 & 1.34 & 0.00 & 16.50 & 9.00 & 49.00 & 7.23 \\
\hline P6 20-50 & 8.04 & 3.27 & 36.97 & 10.90 & 7.46 & 21.26 & 0.42 & 0.00 & 8.00 & 13.0 & 17.00 & 7.02 \\
\hline
\end{tabular}

${ }^{(1)} \mathrm{EC}=$ Electrical conductivity. ${ }^{(2)} \mathrm{SP}=$ Moisture content of the saturation paste. ${ }^{(3)} \mathrm{SAR}=$ Sodium adsorption ratio $\mathrm{SAR}=$ $\left(\mathrm{Na}^{+}\right) /\left[\left(\mathrm{Ca}^{2+}+\mathrm{Mg}^{2+} / 2\right]^{1 / 2}\right.$. 
Table 3 - Cation exchange complex of soil samples before leaching $\left(\mathrm{T}_{0}\right)$.

\begin{tabular}{|c|c|c|c|c|c|c|c|c|}
\hline \multirow{2}{*}{ Samples } & \multirow{2}{*}{$\begin{array}{c}\mathrm{pH} \\
\mathrm{H}_{2} \mathrm{O}\end{array}$} & \multicolumn{4}{|c|}{ Exchangeable Cátions } & \multirow{2}{*}{$\mathrm{CEC}^{(1)}$} & \multirow{2}{*}{$\operatorname{ESP}^{(2)}$} & \multirow{2}{*}{ Classification $^{(3)}$} \\
\hline & & $\mathrm{Ca}^{2+}$ & $\mathrm{Mg}^{2+}$ & $\mathrm{Na}^{+}$ & $\mathrm{K}^{+}$ & & & \\
\hline & $1: 2.5$ & -..... & - n & $\mathrm{cmol}_{\mathrm{c}} \mathrm{kg}$ & $\cdots$ & - & $\%$ & \\
\hline P1 $0-20$ & 6.90 & 6.20 & 5.80 & 0.60 & 0.40 & 13.00 & 4.62 & normal \\
\hline P1 20-50 & 7.20 & 6.30 & 5.10 & 3.10 & 0.10 & 14.60 & 21.23 & sodic \\
\hline P2 $0-20$ & 7.30 & 5.90 & 4.80 & 3.00 & 0.40 & 14.10 & 21.28 & sodic \\
\hline P2 20-50 & 7.50 & 4.80 & 5.00 & 5.10 & 0.20 & 15.10 & 33.77 & sodic \\
\hline P3 0-20 & 7.88 & 6.80 & 5.60 & 2.30 & 0.80 & 15.40 & 14.93 & solodic \\
\hline P3 20-50 & 7.66 & 5.40 & 7.00 & 1.40 & 0.50 & 14.30 & 9.79 & solodic \\
\hline P4 0-20 & 8.10 & 5.50 & 5.90 & 2.70 & 0.70 & 14.80 & 18.24 & sodic \\
\hline P4 20-50 & 8.10 & 6.70 & 5.80 & 2.30 & 0.40 & 15.10 & 15.23 & sodic \\
\hline P5 $0-20$ & 7.50 & 6.80 & 5.10 & 1.50 & 0.70 & 14.10 & 10.64 & solodic \\
\hline P5 20-50 & 7.50 & 5.20 & 6.30 & 2.20 & 0.40 & 14.10 & 15.60 & sodic \\
\hline P6 0-20 & 7.20 & 5.70 & 6.60 & 1.40 & 0.50 & 14.20 & 9.86 & solodic \\
\hline P6 20-50 & 7.40 & 5.40 & 6.80 & 1.30 & 0.20 & 13.70 & 9.49 & solodic \\
\hline
\end{tabular}

${ }^{(1)} \mathrm{CEC}=$ Cation exchange capacity. ${ }^{(2)} \mathrm{ESP}=$ Exchangeable sodium percentage. ${ }^{(3)}$ Classification according to ESP levels.

Table 4 - Soil exchange complex of samples 0 - 20 e 20 - $50 \mathrm{~cm}$ after leaching with water $\left(\mathrm{T}_{1}\right)$ and gypsum saturated water $\left(\mathrm{T}_{2}\right)$.

\begin{tabular}{|c|c|c|c|c|c|c|c|c|c|c|}
\hline \multirow{2}{*}{ Samples } & \multirow{2}{*}{$\begin{array}{c}\mathrm{pH} \\
\mathrm{H}_{2} \mathrm{O}\end{array}$} & \multicolumn{4}{|c|}{ Exchangeable Cátions } & \multirow{2}{*}{$\operatorname{ESP}^{(1)}$} & \multirow{2}{*}{$\begin{array}{c}\left.\operatorname{ESP}^{(2)}\right) \\
\Delta_{\mathrm{i}-\mathrm{f}}\end{array}$} & \multirow{2}{*}{$\mathrm{EC}^{(3)}$} & \multirow{2}{*}{$\begin{array}{c}\mathrm{EC}^{(4)} \\
\Delta_{\mathrm{i}-\mathrm{f}}\end{array}$} & \multirow{2}{*}{ Classification $^{(5)}$} \\
\hline & & $\mathrm{Ca}^{2+}$ & $\mathrm{Mg}^{2+}$ & $\mathrm{Na}^{+}$ & $\mathrm{K}^{+}$ & & & & & \\
\hline & $1: 2.5$ & 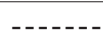 & $--\mathrm{cmol}$ & $\mathrm{kg}^{-1}-$. & -1--- & $\%$ & & $\mathrm{dS} \mathrm{m}^{-1}$ & & \\
\hline \multicolumn{11}{|c|}{ T1 - Leaching with water } \\
\hline P1 $0-20$ & 7.10 & 7.30 & 5.15 & 0.65 & 0.56 & 4.76 & -0.14 & 1.15 & 0.00 & NS \\
\hline P1 20-50 & 7.85 & 6.50 & 5.65 & 2.13 & 0.20 & 14.71 & 6.52 & 1.31 & 3.92 & $\mathrm{SO}$ \\
\hline P2 $0-20$ & 7.60 & 6.40 & 4.75 & 1.00 & 0.79 & 7.73 & 13.55 & 1.16 & 6.84 & NS \\
\hline P2 20-50 & 7.90 & 6.25 & 4.45 & 5.25 & 0.33 & 32.25 & 1.52 & 12.93 & -4.14 & SS \\
\hline P3 $0-20$ & 7.45 & 7.50 & 4.65 & 0.67 & 1.03 & 4.84 & 10.09 & 1.31 & 2.64 & NS \\
\hline P3 20-50 & 7.85 & 6.50 & 6.10 & 1.51 & 0.68 & 10.21 & -0.42 & 1.77 & 1.55 & NS \\
\hline P4 0-20 & 8.00 & 7.90 & 5.50 & 0.69 & 0.65 & 4.68 & 13.56 & 1.41 & 6.69 & NS \\
\hline P4 20-50 & 8.45 & 8.30 & 4.70 & 1.85 & 0.53 & 12.02 & 3.21 & 1.71 & 1.35 & NS \\
\hline P5 $0-20$ & 7.40 & 5.70 & 5.55 & 0.66 & 0.86 & 5.17 & 5.47 & 1.17 & 2.87 & NS \\
\hline P5 $20-50$ & 7.90 & 7.15 & 4.65 & 0.71 & 0.67 & 5.39 & 10.21 & 1.34 & 2.34 & NS \\
\hline P6 $0-20$ & 7.55 & 7.10 & 4.10 & 0.78 & 0.59 & 6.21 & 3.65 & 1.23 & 6.07 & NS \\
\hline P6 20-50 & 7.85 & 7.45 & 4.45 & 1.39 & 0.35 & 10.19 & -0.70 & 1.72 & 1.55 & NS \\
\hline \multicolumn{11}{|c|}{ T2 - Leaching with gypsum saturated water } \\
\hline P1 $0-20$ & 6.00 & 7.25 & 4.55 & 0.71 & 0.84 & 5.32 & -0.70 & 2.95 & -1.8 & NS \\
\hline P1 20-50 & 6.25 & 7.10 & 5.50 & 1.52 & 0.30 & 10.54 & 10.69 & 1.28 & 3.95 & NS \\
\hline P2 $0-20$ & 6.80 & 6.35 & 5.00 & 0.82 & 0.57 & 6.44 & 14.84 & 2.56 & 5.44 & NS \\
\hline P2 20-50 & 7.20 & 6.20 & 5.20 & 3.67 & 0.46 & 13.63 & 20.14 & 2.84 & 5.92 & NS \\
\hline P3 0-20 & 7.35 & 8.10 & 4.65 & 0.82 & 0.88 & 5.67 & 9.26 & 2.18 & 1.77 & NS \\
\hline P3 20-50 & 7.50 & 7.35 & 5.00 & 1.24 & 0.76 & 8.64 & 1.15 & 2.33 & 0.99 & NS \\
\hline P4 0-20 & 7.70 & 7.45 & 5.60 & 0.83 & 0.80 & 5.65 & 12.59 & 2.51 & 5.59 & NS \\
\hline P4 20-50 & 7.80 & 7.75 & 5.35 & 1.98 & 0.57 & 12.65 & 2.58 & 2.08 & 0.98 & NS \\
\hline P5 $0-20$ & 7.15 & 7.10 & 5.10 & 0.82 & 0.72 & 5.97 & 4.67 & 1.84 & 2.20 & NS \\
\hline P5 20-50 & 7.25 & 6.90 & 4.75 & 1.29 & 0.88 & 9.33 & 6.27 & 2.92 & 0.76 & NS \\
\hline P6 0-20 & 7.50 & 8.00 & 4.00 & 0.79 & 0.61 & 5.90 & 3.96 & 2.21 & 5.09 & NS \\
\hline P6 20-50 & 7.40 & 7.45 & 4.75 & 1.40 & 0.42 & 9.99 & -0.50 & 2.53 & 0.74 & NS \\
\hline
\end{tabular}

${ }^{(1)} \mathrm{ESP}=$ Exchangeable sodium percentage. ${ }^{(2)} \mathrm{ESP}_{\mathrm{\Delta}_{\mathrm{i}-\mathrm{f}}}=$ Initial ESP - final ESP. ${ }^{(3)} \mathrm{EC}=$ Electrical conductivity of the saturation extract. ${ }^{(4)} \mathrm{EC}_{\Delta_{\mathrm{i}-\mathrm{f}}}=$ Initial EC - Final EC. ${ }^{(5)} \mathrm{NS}=$ Non saline; $\mathrm{S}=$ Saline; $\mathrm{SS}=$ Saline-sodic e $\mathrm{SO}=$ Sodic. 
only one sample $\left(\mathrm{P}_{0-20}\right)$. The comparison, in absolute values, between $\mathrm{EC}$ after leaching with water and with gypsum saturated water (Table 4) showed that salt concentration in the soil leached with gypsum water was slightly greater than in the soil leached with pure water, except for sample P2 ${ }_{20-50}$. Studying the application of gypsum in a saline-sodic alluvial soil, Holanda et al. (1998) also observed a salinity increase. This salinity increase is normally expected, since gypsum is a source of salts to soil solution. However, the salinity increase occurs only initially. With time, the substitution of $\mathrm{Na}$ for $\mathrm{Ca}$ leads to an improved soil hydraulic conductivity and water infiltration and, consequently, soil salinity will be reduced (Ayers \& Westcot, 1991).

All samples were classified as non-saline after leaching. Following the same behavior of treatment T1, there was a tendency for equilibrium between the EC of the soil solution and EC of the gypsum saturated water $\left(E C=2.07 \mathrm{dS} \mathrm{m}^{-1}\right)$, after leaching. The analysis of variance (Table 5) of data from EC, soil pH, exchangeable cations and ESP, were highly significant $(P<0.01)$ for both treatments (T1 and T2).

The comparison between soil $\mathrm{pH}$ values by the Tukey test $(P=0.05)$ demonstrates that the leaching with gypsum-saturated water reduced soil $\mathrm{pH}$ in relation to the original soil, being different to the treatment without gypsum. These results indicate an effective contribution of gypsum to the reduction of soil $\mathrm{pH}$, which is in agreement with the results obtained by Dubey \& Mondal (1994), Santos (1995) and Holanda et al. (1998). After leaching of the exchangeable sodium, parts of the exchangeable sites are taken by wa- ter-dissociated hydrogen. Furthermore, some bicarbonate responsible for alkalinity is bounded in low solubility complexes with the calcium of the gypsum, also contributing to a $\mathrm{pH}$ decrease. No $\mathrm{pH}$ change in depth was observed.

The average soluble salt concentration (EC) compared by the Tukey test demonstrate that soil leaching treatments were efficient in decreasing the original EC, although no differences $(P>0.05)$ were observed between treatments. After leaching with water (T1) and gypsum saturated water (T2) an increase of exchangeable calcium was observed in relation to the original soil. However, the greatest and different values $(P<0.01)$ were observed after leaching with gypsum-saturated water. Gypsum is a source of calcium and its application in the water improved the amount of this cation in soil solution and, consequently, in the exchangeable sites. Similar results were obtained by application of gypsum directly into the soil (Cavalcante, 1984; Lucena, 1986; Santos, 1995 \& Holanda et al., 1998).

Soil leaching with gypsum saturated water reduced the amount of exchangeable sodium and ESP $(P$ $<0.01)$ in relation to the original soil. On average, the ESP had $46 \%$ reduction and exchangeable sodium was reduced in $46 \%$. There was a difference $(P<0.01)$ in the variation of ESP and exchangeable sodium with depth, with greater values in the $20-50 \mathrm{~cm}$ layer.

In general, no differences were observed in the $\mathrm{EC}, \mathrm{Ca}^{+}$and $\mathrm{pH}$ values in depth but, the $20-50 \mathrm{~cm}$ layer showed increased $\mathrm{Mg}^{2+}, \mathrm{Na}^{+}$and ESP values, in relation to the surface layer. The highest amounts of potassium were observed in the $0-20 \mathrm{~cm}$ layer. The

Table 5 - Average results of soil $\mathrm{pH}$, electrical conductivity (EC), exchangeable calcium, magnesium, sodium and potassium, and exchangeable sodium percentage (ESP) before $\left(\mathrm{T}_{0}\right)$ and after soil leaching with water $\left(\mathrm{T}_{1}\right)$ and gypsum saturated water $\left(\mathrm{T}_{2}\right)$.

\begin{tabular}{|c|c|c|c|c|c|c|c|}
\hline \multirow{2}{*}{ Treatments } & \multirow{2}{*}{$\begin{array}{c}\mathrm{pH} \\
\mathrm{H}_{2} \mathrm{O}\end{array}$} & \multirow{2}{*}{$\mathrm{EC}$} & \multicolumn{4}{|c|}{ Exchangeable cations } & \multirow{2}{*}{ ESP } \\
\hline & & & $\mathrm{Ca}^{2+}$ & $\mathrm{Mg}^{2+}$ & $\mathrm{Na}^{+}$ & $\mathrm{K}^{+}$ & \\
\hline & $1: 2.5$ & $\mathrm{dS} \mathrm{m}^{-1}$ & - - & - cmol & $\mathrm{kg}^{-1}-\ldots \ldots$ & - & $\%$ \\
\hline Original soil $\left(\mathrm{T}_{0}\right)$ & $7.52 \mathrm{a}$ & $4.97 \mathrm{a}$ & $5.89 \mathrm{c}$ & $5.81 \mathrm{a}$ & $2.22 \mathrm{a}$ & $0.44 \mathrm{~b}$ & $15.28 \mathrm{a}$ \\
\hline Water $\left(\mathrm{T}_{1}\right)$ & $7.64 \mathrm{a}$ & $2.35 \mathrm{~b}$ & $6.75 \mathrm{~b}$ & $4.81 \mathrm{~b}$ & $1.59 \mathrm{ab}$ & $0.60 \mathrm{a}$ & $11.18 \mathrm{ab}$ \\
\hline Water+gypsum $\left(\mathrm{T}_{2}\right)$ & $7.15 \mathrm{~b}$ & $2.35 \mathrm{~b}$ & $7.24 \mathrm{a}$ & $5.03 \mathrm{~b}$ & $1.19 \mathrm{~b}$ & $0.61 \mathrm{a}$ & $8.30 \mathrm{~b}$ \\
\hline Layer $0-20 \mathrm{~cm}$ & $7.35 \mathrm{a}$ & $3.00 \mathrm{a}$ & $6.77 \mathrm{a}$ & $5.03 \mathrm{~b}$ & $1.23 \mathrm{~b}$ & $0.67 \mathrm{a}$ & $8.92 \mathrm{~b}$ \\
\hline Layer $20-50 \mathrm{~cm}$ & $7.52 \mathrm{a}$ & $3.45 \mathrm{a}$ & $6.48 \mathrm{a}$ & $5.40 \mathrm{a}$ & $2.11 \mathrm{a}$ & $0.42 b$ & $14.25 \mathrm{a}$ \\
\hline Mean & 7.44 & 3.04 & 6.63 & 5.22 & 1.67 & 0.55 & 11.59 \\
\hline $\mathrm{CV} \%$ & 6.05 & 70.00 & 10.27 & 12.48 & 63.17 & 34.53 & 57.45 \\
\hline msd A & 0.31 & 1.60 & 0.47 & 0.45 & 0.73 & 0.13 & 4.61 \\
\hline msd A/C & - & - & - & - & - & - & - \\
\hline msd C & - & - & - & 0.30 & 0.49 & 0.08 & 3.13 \\
\hline
\end{tabular}


high coefficients of variation obtained for $\mathrm{EC}, \mathrm{Na}^{+}$, ESP and $\mathrm{K}^{+}$are due to the great chemical variability of the samples.

\section{EC and pH of the leaching solutions, hydraulic conductivity and leaching volume/pore volume re- lation}

The $\mathrm{pH}$ and EC results of the leachates, soil hydraulic conductivity and leaching volume/pore volume relation are shown in Table 6, after ten days of leaching. Differences $(P<0.01)$ were observed in relation to time (initial and stabilized) and layer (0 - 20 and $20-50 \mathrm{~cm}$ ), for the $\mathrm{EC}$; and in relation to the leaching water and time, and for $\mathrm{pH}$ values.

The largest salt concentrations were observed in the first leaching solutions and in $0-50 \mathrm{~cm}$ soil columns. The salt concentrations of the leaching solutions decreased with time, demonstrating soil salt removal by the leaching waters, as shown in Figure $2 \mathrm{a}$.
In relation to the behavior of the leaching solution $\mathrm{pH}$, (Figure $2 \mathrm{~b}$ ), the average values obtained by leaching with water presented higher values, in relation to the leaching solution with gypsum saturated water (Table 6). This difference can be attributed to the original $\mathrm{pH}$ of the waters, which showed $\mathrm{pH}$ values of 8.15 and 7.80 for pure and gypsum saturated water, respectively. The results did not differ in depth. During the leaching process, the initial and stabilized measurements showed differences, with greater results for the stabilized time.

Soil hydraulic conductivity was improved by the application of gypsum in the leaching water. Results were two times greater than the ones in the soil leached with pure water. There was a pronounced effect of gypsum in the reduction of soil ESP and in the increase of the saturated flow of water, which can be demonstrated by the higher values of the leaching volume/pore volume relation. The results are comparable to the ones obtained by Shainberg et al. (1982) and Melo (1988).

Table 6 - Average soil $\mathrm{pH}$ and EC results of the leaching solution from treatments with water $\left(\mathrm{T}_{1}\right)$, gypsum saturated water $\left(\mathrm{T}_{2}\right)$, soil hydraulic conductivity and leaching volume/pore volume relation (LV/PV).

\begin{tabular}{|c|c|c|c|c|}
\hline Treatments & $\mathrm{pH}$ & $\mathrm{EC}$ & Hydraulic conductivity & $\mathrm{LV} / \mathrm{PV}$ \\
\hline & & $\mathrm{dS} \mathrm{m}^{-1}$ & $\mathrm{~cm} \mathrm{~h}^{-1}$ & \\
\hline Water $\left(\mathrm{T}_{1}\right)$ & $8.62 \mathrm{a}$ & $10.84 \mathrm{a}$ & $0.37 \mathrm{~b}$ & $0.93 \mathrm{~b}$ \\
\hline Water + gypsum $\left(\mathrm{T}_{2}\right)$ & $8.26 \mathrm{~b}$ & $11.77 \mathrm{a}$ & $0.61 \mathrm{a}$ & $2.30 \mathrm{a}$ \\
\hline Column $0-20$ & $8.41 \mathrm{a}$ & $8.82 \mathrm{~b}$ & $0.47 \mathrm{a}$ & $2.76 \mathrm{a}$ \\
\hline Column 0-50 & $8.46 \mathrm{a}$ & $13.79 \mathrm{a}$ & $0.51 \mathrm{a}$ & $0.47 \mathrm{~b}$ \\
\hline Initial time & $8.24 \mathrm{~b}$ & $20.06 \mathrm{a}$ & $0.65 \mathrm{a}$ & $0.28 \mathrm{~b}$ \\
\hline Final time & $8.64 \mathrm{a}$ & $2.55 \mathrm{~b}$ & $0.33 \mathrm{~b}$ & $2.95 \mathrm{a}$ \\
\hline Mean & 8.44 & 11.31 & 0.49 & 1.61 \\
\hline $\mathrm{CV}(\%)$ & 3.69 & 101.03 & 90.70 & 119.37 \\
\hline msd A & 0.12 & 4.63 & 0.18 & 0.782 \\
\hline msd C & 0.12 & 4.63 & 0.18 & 0.78 \\
\hline msd $\mathrm{T}$ & 0.12 & 4.63 & 0.18 & 0.78 \\
\hline
\end{tabular}

$\mathrm{CV} \%=$ Coefficient of variation. $\mathrm{msd}=$ minimum significant difference. $\mathrm{A}=$ water treatment. $\mathrm{C}=$ columns. Within columns, values followed by different letters are different $(P=0.05$, Tukey test).
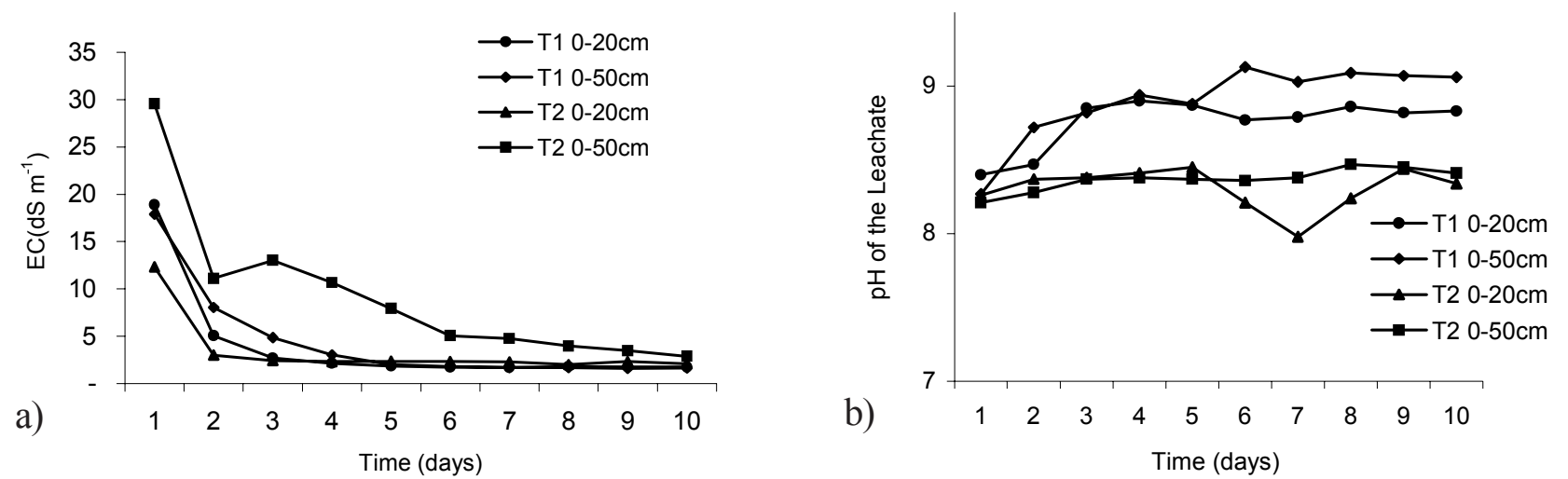

Figure 2 - EC (a) and pH (b) of the leachates related to soil leaching treatments with water (T1) and gypsum-saturated water (T2), in the two layers $(0-20 \mathrm{~cm}$ and $0-50 \mathrm{~cm})$, during ten days. 


\section{CONCLUSIONS}

The use of gypsum in the irrigation water improved soil physical and chemical properties of the studied soils and can be considered as an alternative for the reclamation of saline-sodic and sodic alluvial soils in Northeast Brazil.

\section{REFERENCES}

ANJOS, I.M. Recuperação de um solo salino-sódico: efeito de diferentes níveis e formas de aplicação de gesso. Areia: UFPB, 1993. 34p. Dissertação (Mestrado).

AXTEL, J.D.; DONEEN, J.D. The use of gypsum in irrigation water. Better Crops with Plant Food, v.33, p.16-23, 1949.

AYERS, R.S.; WESTCOT, D.W. A qualidade da água na agricultura. Campina Grande: UFPB, 1991. 218p. (FAO. Irrigação e Drenagem, 29).

BARROS, M.F.C.; MAGALHÃES, A.F. Avaliação de métodos de determinação da necessidade de gesso em solos salino-sódicos. Revista Brasileira de Ciência do Solo, v.13, p.119-123, 1989.

BRESLER, E.; McNEAL, B.L.; CARTER, D.L. Saline and sodic soils: principles, dynamics and modeling. New York: Springer, 1982. $236 \mathrm{p}$.

CAVALCANTE, L.F. Efeito do fosfogesso em solos salinizados da Paraíba, cultivados com feijão vigna. Piracicaba: USP/ESALQ, 1984. Tese (Doutorado).

CHAVES, L.H.G.; ROLIM, H. O efeito da aplicação de sulfato de alumínio e sulfato de cálcio sobre a permeabilidade de um solo. In: CONGRESSO BRASILEIRO DE CIÊNCIA DO SOLO, 26. Rio de Janeiro, 1997. Anais. Rio de Janeiro: SBCS, 1997. 1 CDROM.

DUBEY, S.K.; MONDAL, R.C. Effect of amendments and saline irrigation water on soil properties and yields of rice and wheat in a highly sodic soil. Journal of Agricultural Sciences, v.122, p.351-357, 1994.

DUQUE, J.G. Solo e água no polígono das secas. 4. ed. Fortaleza: DNOCS, 1973. 171p. (Publicação, 154).

EMPRESA BRASILEIRA DE PESQUISA AGROPECUÁRIA. Manual de métodos de análise de solos. 2. ed. Rio de Janeiro: EMBRAPA/CNPS, 1997. 211p.

GOMES, F.P. Curso de estatística experimental. São Paulo: Nobel, 1974. 512p.

HOLANDA, J.S.; VITTI, G.C.; SALVIANO, A.A.C.; MEDEIROS, J.D.F.; AMORIM, J.R.A. Alterações nas propriedades químicas de um solo aluvial salino-sódico, decorrentes da subsolagem e do uso de condicionadores. Revista Brasileira de Ciência do Solo, v.22, p.387-394, 1998.
KELLEY, W.P. Alkali soils: their formation, properties and reclamation. New York: Reinhold, 1951. 176p.

LUCENA, E.R. Efeito da aplicação do fosfogesso em um solo salinosódico. Piracicaba: USP/ESALQ, 1986. 94p. Dissertação (Mestrado).

MELO, F.B., COELHO, M.A.; FERREIRA, H.F.F. Efeito do gesso e da concentração salina da água na condutividade hidráulica do solo. Revista Brasileira de Ciência do Solo, v.12, p.89-92, 1988.

MELO, L.I.A. Avaliação do método de diluições sucessivas de água salina para recuperação de solos salino-sódicos. Recife: UFRPE, 1991. 87p. Dissertação (Mestrado).

PEREIRA, F.A.M. Metodologia de análises químicas para solos afetados por sais no Nordeste. Areia: UFPB, 1981. 71p. Dissertação (Mestrado).

PEREIRA, J.R., VALDIVIESO, G.L.; CORDEIRO, G.G. Recuperação de solos afetados por sódio através do uso de gesso. In: SEMINÁRIO SOBRE O USO DO FOSFOGESSO NA AGRICULTURA, 1., Brasília, 1985. Anais. Brasília: IBRAFÓS, 1986. p.85-105.

PIZARRO, F. Drenaje agrícola y recuperación de suelos salinos. Madri: Española, 1978. 521p.

RAIJ, B. van. Propriedades eletroquímicas do solo. In: SIMPÓSIO AVANÇADO DE QUÍMICA E FERTILIDADE DO SOLO, Campinas, 1986. Resumos. Campinas: Fundação Cargill, 1986. p. $9-42$.

RIBEIRO, M.R. Reabilitação de áreas degradadas em perímetros irrigados do DNOCS em Pernambuco. Recife: UFRPE, 1999. 175p. (Relatório Final de Pesquisa).

RICHARDS, E.A. Diagnostico e rehabilitación de suelos salinos y sodicos. Mexico: Limusa, 1974. 172p.

SANTOS, R.V. Correção de um solo salino-sódico e absorção de nutrientes pelo feijão macassar (Vigna unguiculata L. WALP.). Piracicaba: USP/ESALQ, 1995. 117p. Tese (Doutorado).

SANTOS, R.V.; FERREYRA, F.F.H. Recuperação de solos afetados por sais. In: CONGRESSO BRASILEIRO DE ENGENHARIA AGRÍCOLA, 26., Campina Grande, 1997. Anais. Campina Grande: SBEA, 1997. p.383.

SHAINBERG, I.; KEREN, R.; FRENKEL, H. Response of sodic soils to gypsum and calcium chloride application. Soil Science Society of America Journal, v.46, p.113-137, 1982.

SUMNER, M.E. Sodic soils: new perspectives. In: NAIDU, R.; SUMNER, M.E. (Ed.) Australian sodic soils: distribution, properties and management. Victoria: CSIRO, 1995. p.1-34.

US SALINITY LABORATORY STAFF. Diagnosis and improvement of saline and alkali soils. Washington: US. Government Printing Office, 1954. 160p. (Agriculture Handbook, 60).

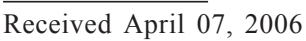

Accepted October 08, 2007 